STUDIA PRAWNO-EKONOMICZNE, t. CV, 2017

PL ISSN 0081-6841; e-ISSN 2450-8179 $\quad$ s. 293-309

DOI: 10.26485/SPE/2017/105/17

Radosław PIETRZYK*

Paweł ROKITA**

\title{
MODEL OPTYMALIZACJI PLANU FINANSOWEGO DWUOSOBOWYCH GOSPODARSTW DOMOWYCH
}

\begin{abstract}
(Streszczenie)
W tym artykule została zaprezentowana oryginalna propozycja modelu planu finansowego dla dwuosobowego gospodarstwa domowego, ze szczególnym uwzględnieniem celu emerytalnego. Koncepcja ta pozwala na stosunkowo łatwe rozszerzanie modelu poprzez dodawanie większej liczby celów, jak również wprowadzanie nowych rodzajów ryzyka. Model ten nie wymaga zastosowania żadnych wyrafinowanych metod kalibracji. Niektóre jego parametry są wprost otrzymywane z publicznie dostępnych danych. Inne to parametry opisujące sytuację finansową gospodarstwa domowego, które są oparte na danych dostępnych każdemu takiemu gospodarstwu (np. dane o bieżących dochodach). Są też parametry wyrażające preferencje członków gospodarstwa domowego (np. ich awersję do ryzyka). Konstrukcja i interpretacja modelu preferencji gospodarstwa domowego przyjęta w proponowanym modelu planu finansowego jest jednak na tyle intuicyjna, że gospodarstwo domowe może po prostu wprost podać te parametry. Koncepcja modelu odnosi się do dwuosobowego gospodarstwa domowego, a nie pojedynczych osób rozpatrywanych osobno. Do zalet podejścia dwuosobowego należy możliwość uwzględnienia takich planów finansowych, w których koszty konsumpcji przypisane do danej osoby nie muszą być w $100 \%$ pokryte w emerytalnej fazie cyklu życia. Staje się to możliwe dzięki dzieleniu ryzyka, a konkretnie poprzez transfer kapitału między członkami gospodarstwa domowego. Liczba możliwych planów finansowych, spośród których wybierany jest plan optymalny, wzrasta w ten sposób znacząco. Podejście dwuosobowe ma jednak swoje wady wynikające $\mathrm{z}$ większej złożoności modelu. Niedogodności wynikające z dwuwymiarowego charakteru procesu przeżycia członków gospodarstwa domowego sprawiaja, że potrzebne są pewne uproszczenia. Sprzyja im oryginalny sposób wyrażania awersji do ryzyka, zaproponowany w ramach tej koncepcji. Pozwala on bowiem na redukcję liczby scenariuszy, które należy uwzględniać w procedurze optymalizacji planu.
\end{abstract}

* Dr, Uniwersytet Ekonomiczny we Wrocławiu; e-mail: radoslaw.pietrzyk@ue.wroc.pl

** Dr, Uniwersytet Ekonomiczny we Wrocławiu; e-mail: pawel.rokita@ue.wroc.pl 
Słowa kluczowe: planowanie finansowe; finanse osobiste; ryzyko długowieczności; modele cyklu życia

Klasyfikacja JEL: C61, D14, D31, D91

\section{Wstęp}

Artykuł ten prezentuje koncepcję modelu planu finansowego gospodarstwa domowego, który, dzięki swojej elastycznej i „,modułowej” konstrukcji, może być łatwo rozbudowywany i modyfikowany. Model ma charakter dyskretny (jest opisany w czasie dyskretnym, a także wszystkie uwzględniane w nim czynniki ryzyka są zmiennymi losowymi o rozkładach dyskretnych). W podstawowej wersji, ilustrującej ogólną koncepcję, jedynym rodzajem ryzyka jest ryzyko związane z długością życia. W modelu nie ma wówczas innych zmiennych losowych niż daty śmierci członków gospodarstwa domowego. Wektor konkretnych wartości tych zmiennych jest nazywany scenariuszem przeżycia. Przy tym zaproponowany tu sposób wyrażania awersji do ryzyka pozwala na ograniczenie liczby scenariuszy przeżycia branych pod uwagę w procedurze optymalizacyjnej. Awersję do ryzyka opisują parametry, których interpretacja jest bardzo intuicyjna i które mogą być wprost podane przez gospodarstwo domowe. Nie wymaga to zastosowania żadnych wyrafinowanych metod szacowania awersji do ryzyka.

Model dotyczy gospodarstwa domowego, a nie pojedynczej osoby. Łączne rozpatrywanie sytuacji finansowej członków gospodarstwa domowego daje wiele korzyści, głównie związanych z możliwością wykorzystania wewnętrznego transferu kapitału. Natomiast niepożądanym efektem takiego podejścia jest jego większa złożoność niż to ma miejsce w przypadku pojedynczych osób traktowanych rozdzielnie. Dotyczy to zwłaszcza wykorzystywanego modelu przeżycia.

Celem badań było stworzenie koncepcji modelu optymalizacji planu finansowego gospodarstwa domowego pozwalającej między innymi na uniknięcie rozważania wszystkich możliwych scenariuszy wielowymiarowego procesu przeżycia w procesie optymalizacji. To powinno ułatwić stosowanie modelu jako podstawy koncepcyjnej dla tworzenia praktycznych narzędzi wspomagających planowanie finansowe gospodarstw domowych w warunkach rzeczywistych.

Pierwsze modele planowania finansowego gospodarstw domowych w cyklu życia, na wzór propozycji Yaari'ego ${ }^{1}$, były oparte na jednoosobowym modelu

M.E. Yaari, Uncertain Lifetime, Life Insurance, and the Theory of the Consumer, The Review of Economic Studies 1965/32 (2), s. 137-150. 
konsumpcji z procesem przeżycia jednej osoby. Dopiero praca Kotlikoffa i Spivaka $^{2}$ wskazała na specyficzne korzyści, jakie w planowaniu finansowym mogą odnosić małżeństwa.

Hurd $^{3}$ zaproponował model konsumpcji w cyklu życia małżeństwa. Przedstawił analityczne rozwiązanie problemu optymalizacji konsumpcji dla małżeństw. Model ten nie miał jednak konstrukcji pozwalającej na jego łatwe przekształcenie w praktyczne narzędzie wspomagające tworzenie planu finansowego (takie narzędzie z natury musi się dać stosunkowo prosto rozbudowywać w sposób pozwalający na uwzględnienie wielu celów, a także umożliwiający dodawanie nowych czynników ryzyka). Nie było to zresztą celem tworzenia tamtego modelu.

Z kolei Brown i Poterba ${ }^{4}$ zbadali m.in. wykorzystanie wspólnych rent dożywotnich dla małżeństw. Badania te nie były poświęcone tworzeniu optymalnego planu finansowego w cyklu życia gospodarstwa domowego, ale, jeszcze bardziej niż poprzednie, podkreślały znaczenie łącznego podejścia.

Wyżej wspomniane badania pokazują, dlaczego całe gospodarstwa domowe (osoby rozpatrywane łącznie) powinny być obiektem zainteresowania współczesnych finansów osobistych. Chociaż niniejszy artykuł nie dotyczy wykorzystania wspólnych produktów rentowych, to jednak motywacją prezentowanych w nim badań jest właśnie wykorzystanie korzyści płynących ze wspólnego rozpatrywania całego gospodarstwa domowego w procesie planowania finansowego.

W planowaniu finansowym obejmującym cykl życia gospodarstwa domowego kluczowym problemem jest zarządzanie ryzykiem związanym z czasem trwania

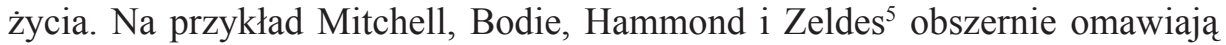
źródła zagrożeń finansowych dla ludzi w starszym wieku i podkreślają szczególne znaczenie celu emerytalnego w planowaniu finansowym.

Problem inwestowania na cel emerytalny jest nieodłącznie związany z problemem właściwej alokacji aktywów. Wymaga to oczywiście wzięcia pod uwagę ryzyka inwestycyjnego i uwzględnienia specyfiki cyklu życia człowieka. Dotyczy to zarówno optymalizacji samej inwestycji, jak i konsumpcji ${ }^{6}$.

2 L.J. Kotlikoff, A. Spivak, The Family as an Incomplete Annuities Market, Journal of Political Economy 1981/89 (2), s. 372-391.

3 M.D. Hurd, Mortality Risk and Consumption by Couples, NBER Working Paper Series 1999.

4 J.R. Brown, J.M. Poterba, Joint Life Annuities and Annuity Demand by Married Couples, Journal of Risk and Insurance 2000/67 (4), s. 527-554.

5 O.S. Mitchell, Z. Bodie, B.P. Hammond, S. Zeldes (eds.), Innovations in Retirement Financing, University of Pennsylvania Press, Philadelphia 2002.

6 H. Huang, M.A. Milevsky, Longevity Risk Aversion and Tax-Efficient Withdrawals, SSRN Electronic Journal 2011; J.M. Poterba, J. Rauh, S. Venti i D. Wise, Lifecycle Asset Allocation Strategies and the Distribution of 401(k) Retirement Wealth, National Bureau of Economic 
W literaturze szeroko omawiany jest również problem dekumulacji kapitału emerytalnego ${ }^{7}$. Jedno z najważniejszych pytań dotyczy tego, czy i w jakim stopniu kapitał emerytalny powinien być wykorzystany do wykupienia renty dożywotniej, aby osiągnąć poziom optymalnej konsumpcji. Davidoff, Brown i Diamond ${ }^{8}$ podają warunki, przy spełnieniu których przeznaczenie całego kapitału emerytalnego na wykupienie renty dożywotniej jest rozwiązaniem optymalnym. Jednym z takich warunków jest brak preferencji pozostawienia spadku. Szeroką analizę wykorzystania rent dożywotnich przedstawiają również Blake, Cairns i Dowd? Z kolei Horneff, Maurer, Mitchell i Rogalla ${ }^{10}$, a także Maurer, Mitchell, Rogalla i Kartashov ${ }^{11}$ pokazują wpływ produktów rentowych na wybór portfela w cyklu życia gospodarstwa domowego.

Omawiana w artykule koncepcja modelu optymalizacji planu finansowego dla gospodarstwa domowego jest w dużym stopniu otwarta w tym sensie, że różne rozwiązania szczegółowe proponowane w literaturze mogą być do niej włączone w różnych konfiguracjach. Jednocześnie udaje się uniknąć nadmiernej komplikacji modelu mimo dopuszczenia łączenia $\mathrm{w}$ nim prawie dowolnych podejść szczegółowych jako jego elementów składowych (np. model użyteczności, model procesu przeżycia, model wyboru i optymalizacji portfela inwestycyjnego itp.).

Research 2006, Cambridge, MA; F. Gomes, L. Kotlikoff, L. Viceira, Optimal Life-Cycle Investing with Flexible Labor Supply: A Welfare Analysis of Life-Cycle Funds, National Bureau of Economic Research 2008, Cambridge, MA.

7 D. Blake, A.J.G. Cairns, K. Dowd, Pensionmetrics 2: stochastic pension plan design during the distribution phase, Insurance: Mathematics and Economics 2003/33 (1), s. 29-47; I. Dus, R. Maurer, O.S. Mitchell, Betting on Death and Capital Markets in Retirement: A Shortfall Risk Analysis of Life Annuities versus Phased Withdrawal Plans, Financial Services Review 2005/14, s. 169-196; G. Gong, A. Webb, Mortality Heterogeneity and the Distributional Consequences of Mandatory Annuitization, Journal of Risk and Insurance 2008/75 (4), s. 1055-1079; H. Huang, M.A. Milevsky, op. cit.; M.A. Milevsky, H. Huang, Spending Retirement on Planet Vulcan: The Impact of Longevity Risk Aversion on Optimal Withdrawal Rates, Financial Analysts Journal 2011/67 (2), s. 45-58.

8 T. Davidoff, J.R. Brown, P.A. Diamond, Annuities and Individual Welfare, SSRN Electronic Journal 2004.

9 D. Blake, A.J.G. Cairns, K Dowd, op. cit., s. 29-47.

10 V. Horneff, R. Maurer, O.S. Mitchell, R. Rogalla, Optimal Life Cycle Portfolio Choice with Variable Annuities Offering Liquidity and Investment Downside Protection, National Bureau of Economic Research 2013, Cambridge, MA.

11 R. Maurer, O.S. Mitchell, R. Rogalla, V. Kartashov, Lifecycle Portfolio Choice With Systematic Longevity Risk and Variable Investment-Linked Deferred Annuities, Journal of Risk and Insurance 2013/80 (3), s. 649-676. 
Prezentacja tej koncepcji stanowi kontynuację badań zawartych m.in. w pracach Feldmana, Pietrzyka i Rokity ${ }^{12}$ oraz Pietrzyka i Rokity ${ }^{13}$.

\section{Założenia modelu}

Przedstawiona w artykule wersja modelu planowania finansowego koncentruje się na celu emerytalnym, ale sama konstrukcja modelu pozwala na elastyczne rozszerzanie go o inne cele finansowe. Omówienie tu podstawowej wersji modelu pozwoli natomiast na bardziej przejrzystą prezentację i skupienie się na koncepcji jego budowy oraz na sposobie przeprowadzenia optymalizacji.

Celami opracowania tej koncepcji było wyeliminowanie konieczności rozważania wszystkich scenariuszy wielowymiarowego procesu przeżycia w procesie optymalizacji planu finansowego, takie skonstruowanie modelu, aby mógł być w prosty sposób skalibrowany, umożliwienie rozbudowywania modelu o nowe cele, sposoby ich finansowania i czynniki ryzyka, a także zastosowanie takich uproszczeń, które rekompensowałyby ewentualny wzrost złożoności w przypadku wspomnianego rozbudowywania modelu, a jednocześnie wiązałyby się z jak najmniejszą utratą istotnej informacji.

Dla zaprezentowania mechanizmu optymalizacji planu, w prezentowanej wersji modelu uwzględniony jest tylko jeden rodzaj ryzyka, a mianowicie ryzyko związane z długością życia (tj. ryzyka przedwczesnej śmierci i ryzyka długowieczności). Jego też dotycząjedyne parametry awersji do ryzyka. Jedynymi zaś zmiennymi losowymi w modelu (czynnikami ryzyka) są daty śmierci członków gospodarstwa domowego.

Model planu finansowego budowany jest dla dwóch osób. Nie oznacza to jednak, że nie można go rozszerzyć na więcej osób. Kotlikoff i Spivak ${ }^{14}$ oraz

12 L. Feldman, R. Pietrzyk, P. Rokita, A Practical Method of Determining Longevity and Premature-Death Risk Aversion in Households and Some Proposals of Its Application, w: M. Spiliopoulou, L. Schmidt-Thieme, R. Janning (eds.), Data Analysis, Machine Learning and Knowledge Discovery, Cham: Springer International Publishing 2014a, s. 255-264.

13 R. Pietrzyk, P. Rokita, On a concept of household financial plan optimization model, Research Papers of Wrocław University of Economics 2015a/(381), s. 299-319; R. Pietrzyk, P. Rokita, Facilitating Household Financial Plan Optimization by Adjusting Time Range of Analysis to Life-Length Risk Aversion, w: A. Wilhelm, H.A. Kestler (eds.), Analysis of Large and Complex Data, Studies in Classification, Data Analysis, and Knowledge Organization. Cham: Springer International Publishing 2016, s. 357-367.

14 L. J. Kotlikoff, A. Spivak, op. cit., s. 372-391. 
Brown i Poterba ${ }^{15}$ wskazują, że para jest typową jednostką podejmującą decyzje w planowaniu finansowym gospodarstw domowych. Zgodnie z tym podejściem jako gospodarstwo dwuosobowe traktujemy gospodarstwo składające się z dwóch osób, które wspólnie podejmują decyzje finansowe i zamierzają tworzyć to gospodarstwo domowe do końca swojego życia. Gospodarstwo jednoosobowe będzie traktowane jako szczególny przypadek, z udziałem drugiej osoby zredukowanym do zera (brak dochodów, brak wydatków itp.). Model powinien jednak dopuszczać uwzględnienie w gospodarstwie domowym również innych osób, które będą rozpatrywane tylko przez pewien czas, a ich obecność ujawnia się w planie finansowym najczęściej w postaci przejściowej modyfikacji struktury konsumpcji, ale też czasem w postaci modyfikacji struktury dochodów. W szczególności takimi osobami są dzieci.

Jak już była o tym mowa we wstępie, prezentowany model jest modelem planowania emerytalnego. Planowanie emerytalne jest głównym elementem długoterminowego planowania finansowego gospodarstwa domowego. Specyficznymi cechami celu emerytalnego są: ograniczona możliwość jego postfinansowania ${ }^{16}$ oraz przeważnie znaczna wartość ( $w$ stosunku do dochodów uzyskiwanych w fazie przedemerytalnej). Należy też mieć na uwadze niewystarczający charakter świadczeń z publicznych systemów emerytalnych w zdecydowanej większości państw świata (mniejsza lub większa luka emerytalna).

W planowaniu finansowym często do rozwiązania problemu zapewnienia dochodów emerytalnych wybiera się rozwiązanie najdroższe. Opiera się ono na przekonaniu, że dochód emerytalny gospodarstwa domowego musi być co najmniej tak duży, jak łączna konsumpcja gospodarstwa domowego oraz że indywidualny dochód emerytalny członków gospodarstwa domowego nie powinien być niższy niż indywidualne potrzeby w okresie emerytalnym. Takie rozwiązanie jest oczywiście bardzo bezpieczne, ale jednocześnie niekoniecznie efektywne z finansowego punktu widzenia. Prowadzi ono bowiem do powielania przychodów na pokrycie wspólnych kosztów oraz nie uwzględnia wykorzystania zgromadzonych nadwyżek finansowych.

Istnieje możliwość zaproponowania innego rozwiązania, które będzie wynikiem optymalizacji całego planu finansowego i będzie dostosowane do awersji do ryzyka gospodarstwa domowego.

15 J.R. Brown, J.M. Poterba, op. cit., s. 527-554.

16 Przykładem postfinansowania może być np. odwrotna hipoteka, ale w rzeczywistości nieruchomość, która miałaby być jej podstawą, musi być wcześniej sfinansowana przez gospodarstwo domowe. 


\section{Ryzyko długości życia i awersja do ryzyka w modelu}

Awersja do ryzyka związanego z długością życia członków gospodarstwa domowego odgrywa kluczową rolę w procesie konstrukcji i optymalizacji planu finansowego. Jak pokazali m.in. Jajuga, Feldman, Pietrzyk i Rokita ${ }^{17}$, liczba rozpatrywanych scenariuszy przeżycia członków gospodarstwa domowego jest bardzo duża. Ponadto, wystąpienie niektórych z nich powodowałoby w realnym życiu co najmniej gruntowną przebudowę planu finansowego, wraz ze zmianą założeń i celów, albo wręcz oznaczałoby powstanie nowego gospodarstwa domowego. Branie ich pod uwagę $w$ procesie optymalizacji planu nie ma więc sensu, nawet gdy ich prawdopodobieństwa nie są pomijalnie małe. W pewnych warunkach nie ma również konieczności uwzględniania scenariuszy przedwczesnej śmierci jednego z członków gospodarstwa domowego tuż przed osiąnnięciem wieku emerytalnego, bo taki scenariusz może nie być zagrożeniem dla planu finansowego, a wręcz przeciwnie - może w sensie finansowym znacznie poprawiać sytuację gospodarstwa domowego. Dlatego też zasadne jest ograniczenie liczby scenariuszy. I właśnie do takiego ograniczenia można wykorzystać proponowany sposób wyrażania awersji do ryzyka.

Autorska propozycja ograniczenia liczy scenariuszy została przedstawiona przez Jajugę, Feldmana, Pietrzyka i Rokitę ${ }^{18}$, a wcześniej także Feldmana, Pietrzyka i Rokitę ${ }^{19}$ oraz Pietrzyka i Rokitę ${ }^{20}$. W tej propozycji awersja do ryzyka związanego z długością życia wyrażona jest w formie parametrów awersji do ryzyka przedwczesnej śmierci $\left(\delta^{*}\right)$ oraz awersji do ryzyka długowieczności $\left(\gamma^{*}\right)$. Gospodarstwo domowe musi zadeklarować, które scenariusze długości życia, to znaczy kończące się, na ile lat przed oraz ile lat po oczekiwanej dacie śmierci, powinny być uwzględnione w procesie optymalizacji. W ten sposób gospodarstwo deklaruje pewien przedział lat (przed i po wartości oczekiwanej) dla każdej z dwóch osób. Powstaje macierz zawierająca scenariusze przeżycia członków gospodarstwa domowego, dla której zaproponowaliśmy nazwę range of concern. Szerszy przedział (wyższe wartości parametrów) oznacza większą awersję do ryzyka - chęć optymalizacji planu dla większej liczby scenariuszy. Węższy przedział (niższe wartości parametrów) oznacza mniejszą awersję do ryzyka długości życia.

17 K. Jajuga, L. Feldman, R. Pietrzyk, P. Rokita, Integrated Risk Model in Household Life Cycle, Publishing House of Wrocław University of Economics 2015.

18 Ibidem.

19 L. Feldman, R. Pietrzyk, P. Rokita, Cumulated Surplus Approach and a New Proposal of Life-Length Risk Aversion Interpretation in Retirement Planning for a Household with Two Decision Makers, SSRN Electronic Journal 2014b.

20 R. Pietrzyk, P. Rokita, op. cit., s. 299-319. 
W szczególnym przypadku gospodarstwo, które nie wykazuje awersji do ryzyka, może optymalizować plan jedynie dla scenariusza oczekiwanego.

Deklarowane parametry $\gamma^{*}, \delta^{*}$ są ustalane wspólnie przez gospodarstwo domowe, a więc nie mogą być traktowane jako indywidualne parametry awersji do ryzyka, ale raczej jako parametry awersji całego gospodarstwa - wynik konsensusu między jego członkami.

Przedział Range of concern gospodarstwa domowego może być zdefiniowane jako:

$$
G_{H}^{*}=\left[E\left(D_{1}\right)-\gamma^{*} ; E\left(D_{1}\right)+\delta^{*}\right] \times\left[E\left(D_{2}\right)-\gamma^{*} ; E\left(D_{2}\right)+\delta^{*}\right],
$$

gdzie:

$\gamma^{*} \quad-$ parametr awersji do ryzyka przedwczesnej śmierci;

$\delta^{*} \quad$ - parametr awersji do ryzyka długowieczności;

$E\left(D_{i}\right)$ - bezwarunkowy oczekiwany czas śmierci osoby $i$.

Parametry $\gamma^{*}, \delta^{*}$ są łatwo interpretowalne, ale ich użycie w modelu wymaga dokonania transformacji. Funkcje oznaczone jako $\gamma(t), \delta(t)$ można interpretować jako dotkliwość (w sensie finansowym) spowodowaną przedwczesną śmiercią lub dłuższym od oczekiwanego życiem. Dotkliwość jest zależna od czasu.

Propozycję konstrukcji miar awersji do ryzyka długości życia przedstawiają Feldman, Pietrzyk i Rokita ${ }^{21}$ oraz Pietrzyk i Rokita ${ }^{22}$. Mogą to być np. funkcje wyrażone równaniami i :

$$
\begin{aligned}
& \gamma(t)=\left\{\begin{array}{cl}
\left(\frac{1}{1+\gamma^{*}}\right)^{\left(\frac{t-E(D)}{E(D)}\right)} & t \leq E(D) \\
0 & t>E(D),
\end{array}\right. \\
& \delta(t)=\left\{\begin{array}{cl}
\left(1+\delta^{*}\right)^{\left(\frac{t-E(D)}{\delta^{*}}\right)} & t>E(D) \\
0 & t \leq E(D),
\end{array}\right.
\end{aligned}
$$

gdzie:

$t$-czas;

$E(D)=\max \left\{E\left(D_{l}\right), E(D 2)\right\}-$ bezwarunkowy oczekiwany czas końca gospodarstwa domowego.

\footnotetext{
L. Feldman, R. Pietrzyk, P. Rokita, op. cit.

R. Pietrzyk, P. Rokita, op. cit., s. 357-367.
} 
Postulowany kształt tych funkcji prezentuje rysunek 1.

RYSUNEK 1: Postulowany ksztalt funkcji $\gamma(t)$ oraz $\delta(t)$

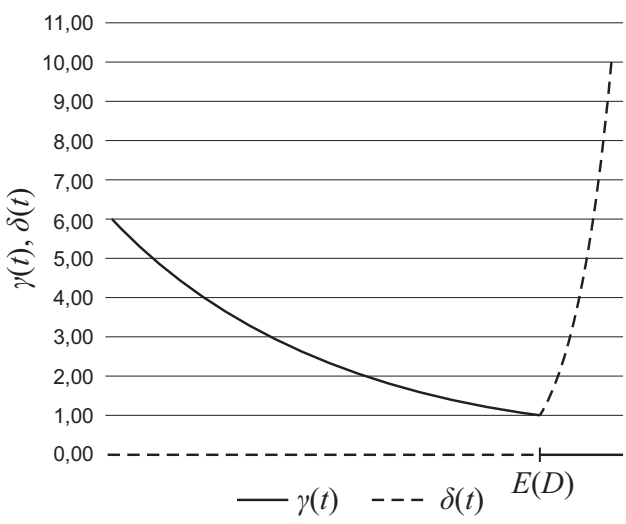

Źródło: opracowanie własne.

Takie ujęcie awersji do ryzyka związanego z długością życia pozwala na ograniczenie się do scenariuszy ze zbioru range of concern oraz na ważenie użyteczności poszczególnych scenariuszy miarą dotkliwości.

\section{Inne preferencje w modelu}

Poza celem emerytalnym, w podstawowej wersji modelu występuje również dążenie do pozostawienia spadku. Cel ten nie jest wprost zadeklarowany z dokładnością co do wartości i czasu realizacji. Czas jego realizacji jest ściśle zależny od trwania życia gospodarstwa domowego. Jego wartość też nie jest ściśle określona. Cel ten został wyrażony jako skłonność gospodarstwa domowego do pozostawienia spadku. A dokładniej - pośrednio, poprzez parametr preferencji konsumpcji. Jej parametr jest znormalizowany w przedziale $[0,1]$. Wartość 1 oznacza, że gospodarstwo zamierza przeznaczyć na konsumpcję wszystkie środki, które nie zostaną zainwestowane z przeznaczeniem na realizację innych celów finansowych. Takie gospodarstwo nie zamierza pozostawić po sobie majątku. W przypadku gdy parametr preferencji konsumpcji przyjmuje wartość mniejszą niż 1, pojawia się preferencja pozostawienia spadku. Oznacza to, że gospodarstwo planuje pozostawienie części zgromadzonego majątku w formie spadku. Gromadzona w trakcie życia nadwyżka finansowa nie ma wówczas na 
celu jedynie zabezpieczenia gospodarstwa domowego przed ryzykiem związanym z długością życia.

Preferencje konsumpcji oraz pozostawienia spadku powinny zatem sumować się do jedności:

$$
\alpha+\beta=1,
$$

gdzie:

$\alpha$ oraz $\beta$ oznaczają odpowiednio preferencję konsumpcji i preferencję pozostawienia spadku.

Dodatkowo część informacji na temat preferencji dotyczących konsumpcji i spadku jest wyrażona również w stopach używanych do dyskontowania użyteczności tych wielkości. Stopa dyskontowania użyteczności konsumpcji $\left(r_{C}\right)$ oraz użyteczności spadku $\left(r_{B}\right)$ są stosowane w modelu, ale nie narzuca się w nim jakiegoś określonego sposobu ustalania ich wartości. Można rozważać trzy podejścia do dyskontowania użyteczności:

1. Różne nastawienie gospodarstwa domowego do konsumpcji i pozostawienia spadku jest wyrażone nie tylko przez parametry preferencji $(\alpha, \beta)$, ale również przez różnicę w wielkości stóp dyskontowania użyteczności. Postuluje się, aby użyteczność konsumpcji była dyskontowana większą stopą niż użyteczność spadku $\left(r C>r_{B}\right)$. Różnica ta wynika $\mathrm{z}$ faktu, że wyrzeczenie się bieżącej konsumpcji na rzecz przyszłej jest trudniejsze z psychologicznego punktu widzenia niż opóźnienie momentu osiaggnięcia pożądanego poziomu nadwyżki pozwalającej na pozostawienie spadku.

2. Preferencja gospodarstwa domowego do konsumpcji i spadku jest wyrażona jedynie raz - w postaci parametrów $\alpha$ i $\beta$. Stopy dyskontowania w tym podejściu również są zróżnicowane $\left(r_{C}>r_{B}\right)$, ale ta różnica jest funkcją parametru $\alpha$.

3. Cała informacja o preferencjach gospodarstwa domowego jest zawarta w parametrach $\alpha$ i $\beta$. W tym podejściu stopy dyskontowania są sobie równe $\left(r_{C}=r_{B}\right)$. Stopy zależą jedynie od rynkowych stóp procentowych i nie maja nic wspólnego z preferencjami gospodarstwa domowego.

Najbardziej użyteczne jest podejście 2 i 3, gdyż celem jest stworzenie prostego i funkcjonalnego narzędzia do optymalizacji planu finansowego gospodarstwa domowego, które będzie łatwe w kalibracji. Ważne jest, aby unikać konieczności deklarowania przez gospodarstwa domowe nieintuicyjnych parametrów. W założeniach modelu zakłada się, że wszystkie dane uzyskiwane od gospodarstw domowych powinny opierać się na obiektywnych i łatwo dostępnych wartościach (np. dochody) lub być intuicyjnie określane przez gospodarstwa domowe, niezależnie od doświadczenia, wykształcenia i pochodzenia społecznego jego członków. 


\section{Optymalizacja planu finansowego}

Optymalizacja planu finansowego polega na maksymalizacji funkcji celu, nazywanej na potrzeby tego modelu funkcją wartości (value function) ${ }^{23}$. Funkcja ta jest oparta na koncepcji oczekiwanej zdyskontowanej użyteczności. Pierwszym składnikiem funkcji wartości jest oczekiwana zdyskontowana użyteczność konsumpcji, a drugim - oczekiwana zdyskontowana użyteczność spadku. W przedstawionym modelu obie funkcje mają tę samą postać analityczną. Różnica występuje w dyskontowaniu - odrębne stopy dla konsumpcji $\left(r_{C}\right)$ i spadku $\left(r_{B}\right)$. Dodatkowo obie składowe funkcji wartości zostały przemnożone odpowiednio przez parametr preferencji konsumpcji $(\alpha)$ i spadku $(\beta)$.

Użyteczność konsumpcji jest obliczana dla każdego scenariusza przeżycia w każdym okresie od momentu $0\left(t_{0}\right)$ do momentu końca życia gospodarstwa domowego w danym scenariuszu. Użyteczność spadku jest obliczana w końcowym momencie gospodarstwa domowego w danym scenariuszu. Funkcja wartości jest zatem sumą przemnażanych odpowiednio przez parametry preferencji konsumpcji i spadku zdyskontowanych użyteczności, obliczanych dla wszystkich scenariuszy pochodzących z range of concern, ważoną prawdopodobieństwami poszczególnych scenariuszy.

W prezentowanej tu podstawowej wersji modelu argumentami funkcji wartości, a zarazem zmiennymi decyzyjnymi procedury optymalizacyjnej są:

- udział konsumpcji w dochodzie gospodarstwa domowego w momencie $t_{0}\left(c_{0}\right)$,

- udział osoby $1 \mathrm{w}$ składce na inwestycję emerytalną całego gospodarstwa domowego w pojedynczym okresie $(v)$.

Funkcja wartości przyjmuje postać daną Wzorem 5:

$V\left(c_{0}, v\right)=$

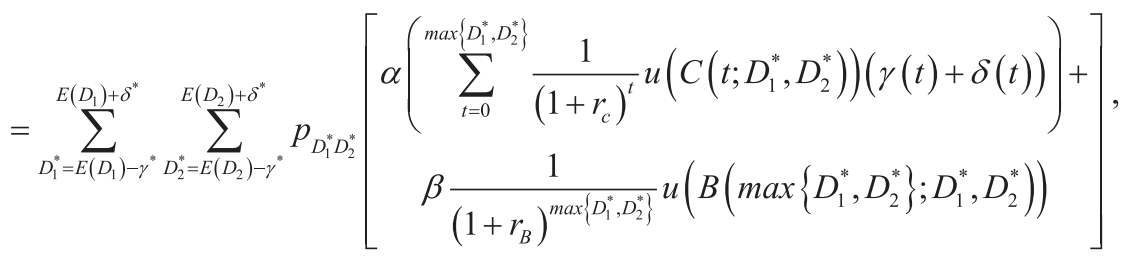

${ }^{23}$ L. Feldman, R. Pietrzyk, P. Rokita, op. cit.; K. Jajuga, L. Feldman, R. Pietrzyk, P. Rokita, Integrated Risk Model in Household Life Cycle, Publishing House of Wrocław University of Economics 2015; R. Pietrzyk, P. Rokita, op. cit., s. 299-319. 
gdzie:

$c_{0} \quad$ - stopa konsumpcji w momencie 0 ;

$v \quad$ - udział osoby $1 \mathrm{w}$ składce na inwestycję emerytalną całego gospodarstwa domowego w pojedynczym okresie $\left(v \equiv v_{1}, v_{1}=1-v_{2}\right)$;

$u($.$) \quad - funkcja użyteczności (taka sama dla konsumpcji i spadku);$

$p_{D_{1}^{*} D_{2}^{*}}$ - bezwarunkowe prawdopodobieństwo scenariusza takiego, że: $\left(D_{1}=D_{1}^{*}, D_{2}=D_{2}^{*}\right)$;

$\alpha \quad$ - parametr preferencji konsumpcji;

$\beta \quad-$ parametr preferencji spadku;

$r_{C} \quad$ - stopa dyskontowania konsumpcji;

$r_{B} \quad$ - stopa dyskontowania spadku;

$\max \left\{D_{1}^{*}, D_{2}^{*}\right\}$ - czas trwania gospodarstwa domowego w scenariuszu $\left(D_{1}=D_{2}^{*}\right.$, $\left.D_{2}=D_{2}^{*}\right)$

$C\left(t, D_{1}^{*}, D_{2}^{*}\right) \quad$ - konsumpcja w momencie $t$ w scenariuszu $\left(D_{1}^{*}, D_{2}^{*}\right)$;

$B\left(\max \left\{D_{1}^{*}, D_{2}^{*}\right\} ; D_{1}^{*}, D_{2}^{*}\right)$-wartość spadku (skumulowane inwestycje i nadwyżka finansowa gospodarstwa domowego) w momencie $t$ w scenariuszu $\left(D_{1}^{*}, D_{2}^{*}\right)$; dla $t=\max \left\{D_{1}^{*}, D_{2}^{*}\right\}$

Optymalizacja planu finansowego polega na zmaksymalizowaniu funkcji wartości:

$$
V(c, v) \rightarrow \max ,
$$

przy następujących ograniczeniach:

- stopa konsumpcji jest nie mniejsza niż minimalna stopa deklarowana przez gospodarstwa domowe,

- cały dochód gospodarstwa domowego jest dzielony pomiędzy konsumpcję i składkę na inwestycję emerytalną,

- cel emerytalny musi zostać osiagnięty (zakładana ścieżka konsumpcji musi zostać zrealizowana w całym cyklu życia gospodarstwa domowego, czyli również po przejściu na emeryturę).

Dodatkowo procedura optymalizacji została zmodyfikowana ${ }^{24}$. Modyfikacja polega na przyjęciu przez sumę zdyskontowanych użyteczności wartości tej sumy tylko w przypadku, gdy skumulowana nadwyżka finansowa w danym scenariuszu na końcu jego trwania jest większa lub równa 0 . Gdy zaś wartość skumulowanej nadwyżki finansowej w tym scenariuszu jest mniejsza od 0 , za sumę zdyskontowanych użyteczności dla scenariusza podstawia się wartość 0 .

${ }^{24}$ L. Feldman, R. Pietrzyk, P. Rokita, op. cit.; K. Jajuga, L. Feldman, R. Pietrzyk, P. Rokita, op. cit. 
Oznaczmy:

$U\left(c_{0}, v ; D_{1}^{*}, D_{2}^{*}\right) \quad$ - suma zdyskontowanych użyteczności dla danego scenariusza;

$\operatorname{CSp}\left(\max \left\{D_{1}^{*}, D_{2}^{*}\right\} ; D_{1}^{*}, D_{2}^{*}\right)$ - skumulowana nadwyżka finansowa na końcu trwania gospodarstwa domowego w danym scenariuszu.

Oznaczmy też modyfikację wartości zdyskontowanych użyteczności w danym scenariuszu przez $U^{\prime}($.$) :$

$$
U^{\prime}\left(c_{0}, v ; D_{1}^{*}, D_{2}^{*}\right)=\left\{\begin{array}{ccc}
U\left(c_{0}, v ; D_{1}^{*}, D_{2}^{*}\right), & \text { jeżeli } & C S p\left(\max \left\{D_{1}^{*}, D_{2}^{*}\right\} ; D_{1}^{*}, D_{2}^{*}\right) \geq 0 \\
0, & \text { jeżeli } & C S p\left(\max \left\{D_{1}^{*}, D_{2}^{*}\right\} ; D_{1}^{*}, D_{2}^{*}\right)<0
\end{array} .\right.
$$

Dlatego też formalnie funkcja wartości, będąca faktycznie przedmiotem optymalizacji, jest dana jako $V^{\prime}($.$) :$

$$
V^{\prime}\left(c_{0}, v\right)=\sum_{D_{1}^{*}=E\left(D_{1}\right)-\gamma^{*}}^{E\left(D_{1}\right)+\dot{\gamma}^{*}=E\left(D_{2}\right)-\gamma^{*}} p_{D_{1}^{*} D_{2}^{*}}^{E\left(D_{2}\right)+\delta^{*}}\left[U^{\prime}\left(c_{0}, v ; D_{1}^{*}, D_{2}^{*}\right)\right] .
$$

Modyfikacja ta ma na celu wzmocnienie efektu „karania” planów finansowych za występowanie w nich scenariuszy, które kończą się niedoborem finansowym ${ }^{25}$.

Wynikiem optymalizacji (maksymalizacji funkcji $\left.V^{\prime}().\right)$ jest para optymalnych wartości zmiennych $\left(c_{0}^{(\text {optim })}, v^{(o p t i m)}\right)$. Dla wprowadzonych założeń oraz ograniczeń modelu zmienne te w pełni opisują optymalny plan finansowy.

Rezultat procesu optymalizacji może zostać zilustrowany przez wykres kształtowania się skumulowanej nadwyżki finansowej gospodarstwa domowego w całym cyklu jego życia. Rysunek 2 prezentuje oczekiwaną strukturę terminową skumulowanej nadwyżki finansowej dla dwóch zoptymalizowanych planów. Nawet analiza jednego tylko scenariusza, oczekiwanego, pozwala na zaobserwowanie charakterystycznej różnicy między planami odpowiadającymi różnemu poziomowi awersji do ryzyka.

25 Skumulowany niedobór na końcu oznacza, że cele finansowe nie mogły zostać zrealizowane, a wymuszenie ich realizacji spowodowałoby niedobór finansowy, z którego gospodarstwo domowe nie byłoby w stanie wyjść. 
RYSUNEK 2: Oczekiwana struktura terminowa skumulowanej nadwyżki finansowej dla planów optymalnych zoptymalizowanych przy różnych wartościach parametrów awersji do ryzyka dlugości życia

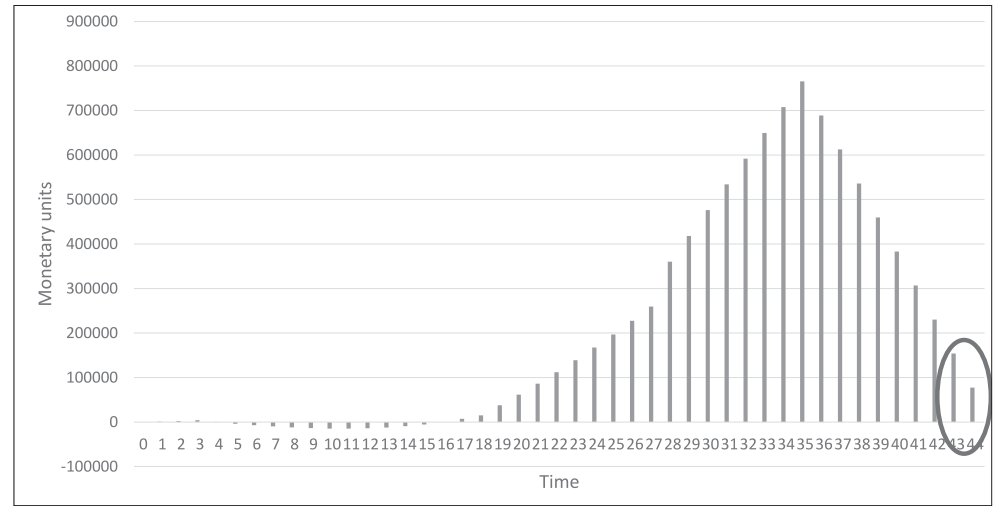

Mniejsza awersja do ryzyka

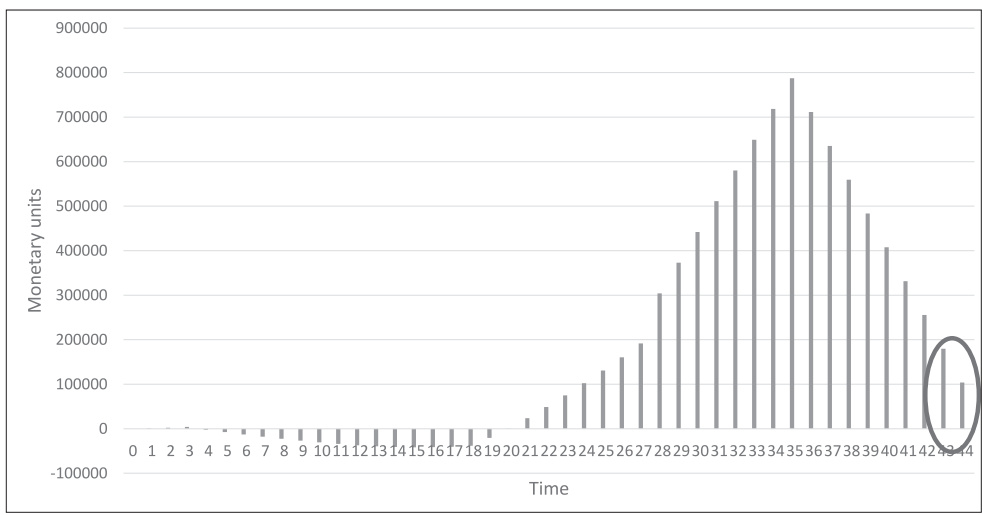

Większa awersja do ryzyka

Źr ó d ło: opracowanie własne.

W pierwszym przypadku (górny wykres na rys. 2) gospodarstwo domowe zadeklarowało mniejszą awersję do ryzyka (węższy range of concern - mniej scenariuszy wziętych pod uwage przy optymalizacji planu). W drugim przypadku (dolny wykres na rys. 2) gospodarstwo zadeklarowało większą awersję do ryzyka (szerszy range of concern - więcej scenariuszy uwzględnionych przy optymalizacji). Procedura optymalizacyjna w drugim przypadku doprowadziła do powstania większej rezerwy finansowej - większa wartość nadwyżki finansowej w ostatnim okresie w scenariuszu oczekiwanym. 


\section{Podsumowanie}

Zaprezentowany model dla dwuosobowego gospodarstwa domowego posiada wiele cech, które sprawiają, że jest jednocześnie ogólny i elastyczny, jak i stosunkowo prosty w aplikacji. Model pozwala na zastosowanie dowolnego modelu dwuosobowego procesu przeżycia dla obliczania prawdopodobieństw poszczególnych scenariuszy. Również nie ogranicza się do jednej konkretnej postaci funkcji użyteczności konsumpcji (to samo dotyczy użyteczności spadku).

Konstrukcja modelu pozwala na rozszerzenie o inne rodzaje ryzyka niż ryzyko czasu trwania życia, a także o inne cele niż cel emerytalny. Inne czynniki ryzyka mogą zostać włączone do modelu zgodnie z zaprezentowanym schematem. Zwiększa to zwykle jedynie liczbę rozpatrywanych scenariuszy, zależnych od tych czynników. Tylko niekiedy może się to również wiązać ze zwiększeniem wymiaru samego zadania optymalizacyjnego. Jest tak wtedy, gdy dochodzi nowa zmienna decyzyjna, co nie zawsze musi towarzyszyć rozszerzaniu modelu. Przy tym, wprowadzenie nowej zmiennej decyzyjnej jest częściej potrzebne, gdy zostanie dodany nowy cel, niż po uwzględnieniu nowego czynnika ryzyka. Na przykład, jeżeli cel może być częściowo prefinansowany, a częściowo finansowany długiem, to nową zmienną decyzyjną będzie wysokość wkładu własnego. Propozycje rozszerzenia modelu o inne kategorie ryzyka i inne cele zostały zaprezentowane m.in. przez Feldmana, Jajugę, Pietrzyka i Rokitę ${ }^{26}$ oraz Pietrzyka i Rokitę ${ }^{27}$.

\section{Bibliografia}

Blake David, Cairns Andrew J.G., Dowd Kevin, Pensionmetrics 2: stochastic pension plan design during the distribution phase, Insurance: Mathematics and Economics 2003/33 (1), s. 29-47.

Brown Jeffrey R., Poterba James M., Joint Life Annuities and Annuity Demand by Married Couples, Journal of Risk and Insurance 2000/67 (4), s. 527-554.

Davidoff Thomas, Brown Jeffrey R., Diamond Peter A., Annuities and Individual Welfare, SSRN Electronic Journal 2004, http://www.ssrn.com/abstract=405621; stan na 7.01.2015 r.

Dus Ivica, Maurer Raimond, Mitchell Olivia S., Betting on Death and Capital Markets in Retirement: A Shortfall Risk Analysis of Life Annuities versus Phased Withdrawal Plans, Financial Services Review 2005/14, s. 169-196.

K. Jajuga, L. Feldman, R. Pietrzyk, P. Rokita, op. cit.

7 R. Pietrzyk, P. Rokita, Stochastic goals in household financial planning for a two-person household, STATISTICS IN TRANSITION new series, 2015b/16 (1), s. 111-136; R. Pietrzyk, P. Rokita, op. cit., s. 357-367. 
Feldman Lukasz, Pietrzyk Radosław, Rokita Pawel, A Practical Method of Determining Longevity and Premature-Death Risk Aversion in Households and Some Proposals of Its Application, w: Myra Spiliopoulou, Lars Schmidt-Thieme, Ruth Janning (eds.), Data Analysis, Machine Learning and Knowledge Discovery, Cham: Springer International Publishing 2014a, s. 255-264.

Feldman Lukasz, Pietrzyk Radosław, Rokita Pawel, Cumulated Surplus Approach and a New Proposal of Life-Length Risk Aversion Interpretation in Retirement Planning for a Household with Two Decision Makers, SSRN Electronic Journal 2014b, http://www.ssrn.com/abstract=2473156; stan na 4.02.2015 r.

Gomes Francisco, Kotlikoff Laurence, Viceira Luis, Optimal Life-Cycle Investing with Flexible Labor Supply: A Welfare Analysis of Life-Cycle Funds, National Bureau of Economic Research 2008, Cambridge, MA.

Gong Guan, Webb Anthony, Mortality Heterogeneity and the Distributional Consequences of Mandatory Annuitization, Journal of Risk and Insurance 2008/75 (4), s. 1055-1079.

Horneff Vanya, Maurer Raimond, Mitchell Olivia, Rogalla Ralph, Optimal Life Cycle Portfolio Choice with Variable Annuities Offering Liquidity and Investment Downside Protection, National Bureau of Economic Research 2013, Cambridge, MA.

Huang Huaxiong, Milevsky Moshe A., Longevity Risk Aversion and Tax-Efficient Withdrawals, SSRN Electronic Journal 2011, http://www.ssrn.com/abstract=1961698; stan na 2.06.2015 r.

Hurd Michael D., Mortality Risk and Consumption by Couples, NBER Working Paper Series 1999, http://www.nber.org/papers/w7048.pdf

Jajuga Krzysztof, Feldman Lukasz, Pietrzyk Radosław, Rokita Pawel, Integrated Risk Model in Household Life Cycle, Publishing House of Wrocław University of Economics, 2015.

Kotlikoff Laurence J., Spivak Avia, The Family as an Incomplete Annuities Market, Journal of Political Economy 1981/89 (2), s. 372-391.

Maurer Raimond, Mitchell Olivia S., Rogalla Ralph, Kartashov Vasily, Lifecycle Portfolio Choice With Systematic Longevity Risk and Variable Investment-Linked Deferred Annuities, Journal of Risk and Insurance 2013/80 (3), s. 649-676.

Milevsky Moshe A., Huang Huaxiong, Spending Retirement on Planet Vulcan: The Impact of Longevity Risk Aversion on Optimal Withdrawal Rates, Financial Analysts Journal, 2011/67 (2), s. 45-58.

Mitchell Olivia S., Bodie Zvi, Hammond Brett P., Zeldes Stephen (eds.), Innovations in Retirement Financing, University of Pennsylvania Press, Philadelphia 2002.

Pietrzyk Radosław, Rokita Pawel, On a concept of household financial plan optimization model, Research Papers of Wrocław University of Economics 2015a/(381), s. 299-319.

Pietrzyk Radosław, Rokita Pawel, Stochastic goals in household financial planning for a two-person household, STATISTICS IN TRANSITION new series 2015b/16 (1), s. 111-136.

Pietrzyk Radosław, Rokita Pawel, Facilitating Household Financial Plan Optimization by Adjusting Time Range of Analysis to Life-Length Risk Aversion, w: Adalbert Wilhelm, Hans A. Kestler (eds.), Analysis of Large and Complex Data, Studies in Classification, Data Analysis, and Knowledge Organization. Cham: Springer International Publishing, 2016, s. 357-367.

Poterba James M., Rauh Joshua, Venti Steven, Wise David, Lifecycle Asset Allocation Strategies and the Distribution of 401(k) Retirement Wealth, National Bureau of Economic Research 2006, Cambridge, MA.

Yaari Menachem E., Uncertain Lifetime, Life Insurance, and the Theory of the Consumer, The Review of Economic Studies 1965/32 (2), s. 137-150. 
Radosław PIETRZYK

Paweł ROKITA

\section{FINANCIAL PLAN OPTIMIZATION MODEL FOR A 2-PERSON HOUSEHOLD}

( Sum mary)

This article presents an original proposal of a two-person household financial plan optimization model, with a special emphasis on the retirement goal. The concept allows for relatively easy augmenting of the model, by adding more goals to it, as well as introducing new types of risk. The model does not require any sophisticated estimation of parameters. Some of them are obtainable directly from publicly known data. Some other describe the financial situation of the household and are based on the data that each household has the access to (e.g., current income of the household members). There are also the parameters that reflect preferences of the household members (e.g., their risk aversion). The construction and interpretation of preferences in the model is intuitive, thanks to which, the preference parameters may be directly provided by the household members. No sophisticated estimation is needed. The concept refers to a two-person household, instead of treating household members as independent single individuals. To the advantages of a two-person model belongs the fact that it allows for such financial plans, in which the costs that are attributed to each particular person do not need to be covered in $100 \%$ during the retirement phase of the life cycle. This is possible thanks to the risk sharing by the household members, or, to be more precise, thanks to the capital transfer between them. A two-person approach has, however, its disadvantages resulting from higher level of complexity. Some problems of the burdensomeness resulting from the bi-dimensionality had to be overcome. An original way of risk aversion expressing, proposed as part of the concept, enables the necessary simplification. It allows to reduce the number of scenarios to be taken into consideration in the procedure of plan optimization.

Keywords: financial planning; personal finance; longevity risk; life-cycle models 